\title{
Var Marquis de Sade sadist?
}

Marquis de Sade træder ind på scenen på et tidspunkt, hvor solen er ved at gå ned over oplysningstiden og libertinerkulturen. Det synspunkt, som jeg vil argumentere for i denne tekst, er, at Sades tekster (sammen med tekster af samtidige forfattere som Vivant Denon, Pierre Choderlos de Laclos og Giacomo Casanova) gør det muligt for os at forstå, hvorfor libertineridealet, der dominerer en stor del af det 18 . århundredes litterære produktion, forsvinder nærmest sporløst fra den ene dag til den anden for først at dukke op igen knap halvandet hundrede år efter med GuillaumeApollinaire og surrealisterne. Som mange af de andre store libertinerværker (først og fremmest Laclos' Farlige Forbindelser) udgør Sades skrifter nemlig ikke en hyldest til, men en radikal kritik af libertineridealet. Det vil med andre ord sige, at Sades værker heller ikke er en hyldest til den uhæmmede lyst og det frie begær. De udforsker derimod libertineridealet, tager det på ordet, afslører dets forudsætninger og viser dets fatale konsekvenser. Eller for at sige det endnu mere direkte: Det, som Sade viser i sine bøger, er ikke en seksuel utopi; det er en seksuel dystopi.

Det er en lidet overraskende pointe for alle, der har bladret bare en smule i Sades skrifter. Det er de færreste, der virkelig tænder på Sades bøger, og skuffelsen var derfor udbredt, da der i 2007 blev udgivet et udvalg af hans tekster på dansk. Hans Bjerregaard i Ekstra Bladet slår meget præcist tonen an:

64 Marquis de Sades sadisme handler ikke om ti kokette rap i enden og en pirrende klemme i en brystvorte. Her er incest, pædofili, tortur, voldtægt og mishandling, der oftest kulminerer i brutale drab. Udskejelserne er beskrevet i et plumpt, usanseligt sprog, og de er pinagtigt ensformige. Bogen er aldeles blottet for onani-værdi. Samtidig er dens fors $ø$ g på at retfærdiggøre grusomhederne i alenlange diskussioner så dræbende kedsommeligt, at der helt i forfatterens ånd nærmest er tale om tortur af læseren. ${ }^{\mathrm{I}}$

Det overraskende er måske snarere, at Sade overhovedet er blevet forbundet med seksuel frigørelse og seksuel lyst (anmeldernes skuffelse er derfor fuldt forståelig). 
Man behøver bare at tænke på Anne Linnets funkband fra firserne, Marquis de Sade: Sade som ikon for det frisatte begær og den kreative erotik. Sådan er det i populærkulturen i dag, sådan har det egentlig altid været, og sådan er det også hos kenderne. André Breton (og den surrealistiske bevægelse generelt, Paul Éluard, Robert Desnos) har således en tendens til at læse det seksuelle hos Sade bogstaveligt, au premier degré, dvs. uden at spørge sig selv, om Sades skrifter nu også i virkeligheden propaganderer for disse djævelsk udspekulerede og grænsesøgende horebukke, der gør kvinderne frie ved - paradoksalt nok - at gøre dem til deres slaver.

Sade er blevet læst medicinsk, psykoanalytisk, politisk, religiøst, æstetisk, men med hensyn til det seksuelle er han næsten konsekvent blevet læst au premier degré. Da han døde i 1814, stod han som inkarnationen af det absolut onde, og i det meste af det 19. århundrede var der næppe nogen litteraturkritiker, der turde hviske hans navn. Det blev lægerne, der tog over. Den tyske læge Richard Krafft-Ebing nævnte Sade i et værk om afvigende seksualitet, Psychopathia Sexualis fra 1886, ${ }^{2}$ og i 1899 definerede den franske læge Claude Tournier (der skrev under pseudonymet Dr. Marciat) begrebet sadisme. Sade var på vej til at blive rehabiliteret. På trods af (og lidt senere på grund af) sine perversioner var han en tænker, som det var værd at beskæftige sig med, en forgænger for Freud, en kender af menneskesjælen, én der havde set det indre dyr i øjnene.

Så blev Sade generobret af litteraterne. Det begyndte med Apollinaire, der i sin meget softcore introduktion til Sade fra 1909 fremstillede ham som symbolet på en tredobbelt frigørelsesproces: kvindernes seksuelle frigørelse, folkets frigørelse fra enevælden, sprogets frigørelse. ${ }^{3}$ Disse temaer blev direkte overtaget af den surrealistiske bevægelse få år efter, og det er mere eller mindre dér, vi er i dag: Sade, den fordømte digter, der udfordrer de religiøse, sociale og seksuelle konventioner. Alain Robbe-Grillet ser således torturen hos Sade som "kærtegnets yderste hyldest til skønheden"4 (altså temaet om seksuel frigørelse). Hos Roland Barthes er det den sproglige frigørelse, der tematiseres. Barthes fjerner stort set enhver referentiel dimension hos Sade; de forvredne og blodige kroppe bliver til en retorisk kombinatorik, og Sade selv bliver til en slags tidlig poststrukturalist (En præ-poststrukturalist?). ${ }^{5}$ Endelig hos Pierre Klossowski, Georges Bataille og Maurice Blanchot ser vi den nærmest religiøse Sade, der søger det absolutte: et fjernt, fjernt sted, hvor grænsen mellem godt og ondt er forsvundet. Under alle omstændigheder er det blot variationer over det samme tema. Sade: det sorte ikon for den frigørende overskridelse.

Det er her, man begynder at få en mistanke om, at alle disse navne (de største og mest hårdkogte hjerner i hundrede års fransk litteraturkritik) måske har udnyttet eller måske endda ligefrem misbrugt Sade. Hans umådelige radikalitet bliver et tomt tegn, som de kan projicere deres egne tanker om politisk, litterær, religiøs og seksuel revolution over i. Denne pointe kan illustreres af modtagelsen af Pierre Klossowskis bog Sade, mon prochain i 1947. Det er på mange måder en uhyre inspireret læsning af Sade. Det er dog temmelig svært at skelne mellem, hvor meget der er Sade, og hvor meget der er Klossowski i den, for Klossowski forsøger at forstå Sade som en tøvende og skyldplaget troende. Surrealisterne reagerede meget voldsomt på denne tolkning. I deres øjne var Sade sammen med Lautréamont hovedfiguren i, hvad man kan kalde "De nådeløses evangelium": to figurer, der ikke tilgiver, og 
som heller ikke selv må blive tilgivet. For at Sade til stadighed skulle kunne fremstå som ikonet for den ultimative overskridelse, måtte han beskyttes mod dem, der ville tilgive ham, forløse ham, normalisere ham og gøre ham til en skribent blandt andre skribenter. Denis Hollier karakteriserer rammende den surrealistiske reaktion således: "There are authors one wants to hoard, that one wants to reserve for oneself like a woman one doesn't want to share. They must be protected against those who are in danger of loving them, against their admirers even more than against their detractors."

For surrealisterne repræsenterer Sade altså det absolutte, men for at få ham placeret på den rigtige plads i deres poetik, er de nødt til 1) at forstå romanerne og deres absurde handlinger helt bogstaveligt; 2) at forstå det, som Sade selv siger om sit værk, mere eller mindre ironisk. Denne dobbelte operation gør, at Sade stort set bliver til talsmand for det, han går til angreb på. Det er en pointe, som jeg har tænkt mig at argumentere for på følgende måde. Først vil jeg som oplæg give en lille præsentation af konteksten, libertineridealet, det 18. århundredes libertinerromaner og en kort præsentation af Sades liv. Dernæst vil jeg diskutere De 120 dage i Sodoma og endelig prøve at afklare Sades forhold til det libertinerideal, der er omdrejningspunktet i hans bøger.

\section{Libertineridealet}

Når man taler om libertinerlitteratur, er det vigtigt at præcisere, hvad betegnelsen dækker over. Ordet libertiner bruges først af den franske reformator Calvin som en stærkt nedsættende betegnelse for folk, der ikke accepterede protestantismens, dvs. Calvins, lære og sandhed: skørlevninge, horebukke, folk uden tro og moral. I det 17. århundrede, Solkongens århundrede, er betegnelsen stadig belastet, men nu ikke mere end at enkelte tænkere selv kalder sig libertinere. Det 17. århundredes libertiner er en epikuræer, en fritænker, en skeptiker, der forholder sig tvivlende til de kristne dogmer. Det er en teoretisk libertinage. Men i det 18. århundrede får denne filosofiske libertinage en praktisk dimension; teserne prøves af i det virkelige liv. Religionens moralske læresætninger forkastes med henvisning til naturen: krop og sjæl er et, og det er forkert at hæmme det frie begær. Fornøjelser - særlig de erotiske - bliver legitimeret.

Denne nye kønsmoral bliver et centralt tema i Oplysningstidens litteratur, men skønt temaet er det samme, er der to skarpt adskilte tendenser i libertinerromanen. Der er den uproblematiske libertinage, der bliver fremstillet i en række erotiske (eller rettere pornografiske) romaner. Det er romaner, hvis verden minder meget om pornoens utopia: det fysiske begær er frit og uhæmmet, alle er altid glade, og der er ingen forhindringer og ingen pris at betale. Det er livet som en evig sengekantfilm (L'académie des dames, Mémoires turcs, Thémidore, Thérèse philosophe, La belle Cauchoise, plus Nicolas Restif de la Bretonnes talløse romaner). Dertil kommer en række utopier, hvoraf den mest kendte er Étienne-Gabriel Morrellys Basiliade fra 1753.

Det er imidlertid bemærkelsesværdigt, at de egentlige mesterværker i det 18. århundredes erotiske litteratur - dem som vi normalt kalder for libertinerromaner - 
yderst sjældent laver propaganda for denne praktiske libertinage. Man tror simpelthen ikke på, at libertineridealet er muligt. Med god grund: en verden, hvor mænd og især kvinder var permanent disponible for sex og erotik, var temmelig langt væk fra dagliglivet i det 18. århundrede. Crébillon fils, Charles Duclos og Laclos viser libertinagen som noget problematisk og ganske farligt, og libertinerne fremstilles som hyklere og sociale skadedyr.

Libertineridealet hviler på to illusioner. For det første hævdes det, at det seksuelle begær er som en gnist fra det guddommelige, der viser os vejen mod det gode. Det er en kult, hvor orgasmen bliver kilde til højere indsigt. Uanset hvad vi begærer, er begæret godt og kræver, at vi tilfredsstiller det. Selve beviset for det er den fysiske nydelse: Ville Gud have skabt noget så behageligt, hvis ikke han gik ind for det? Libertineren påstår, at han handler i overensstemmelse med et højere ideal - naturens eller Guds plan - og at han selv tilhører en slags højere menneskehed. Han har indset tingenes rette sammenhæng, og han hævder, at det er hans mission at frigøre andre, så de kan komme op på hans niveau. Men den frigørelse og overmenneskelighed, som libertineren stiller sine ofre i udsigt, er bare blændværk. Som Valmont og Merteuil i Farlige Forbindelser foragter han alle andre og mener, at kun han selv er noget værd.

Den anden illusion går ud på at lade, som om manden og kvinden er lige i dette spil. Libertineren prøver at få det til at se ud, som om kvinden har lige så meget at vinde og lige så lidt at tabe som han selv. Intet er mindre sikkert. Der er ingen frigørelse, der venter på kvinden, bare social déroute. Når den fysiske kontakt én gang er etableret mellem libertineren og hans offer, falder masken, og det viser sig, at mandens og kvindens interesser er direkte modstridende. Kvinden har brug for diskretion, libertineren for offentlighed, for sejren tæller ikke, hvis ikke den bliver skreget ud fra tagene. Hvad ville erobringen være værd, hvis der ikke er vidner? Reklamen er langt vigtigere end det galante eventyr i sig selv.

Derfor er listen så nødvendig for libertineren. Don Juan har sin berømte liste, møjsommeligt ajourført af Leporello over sine tusind og tre (mille et tre) erobringer i Spanien, og Casanova har sine erindringer, hvor han ikke glemmer at bogføre selv det mindste eventyr. Det drejer sig ikke om at få eller give glæde her. Det drejer sig om magt og anseelse. Det drejer sig om at blive beundret og misundt. Libertinagen går ud på at veksle sex til social prestige for libertineren selv og til social nedtur for deres elskerinder.

Det er i det perspektiv fuldstændig absurd at give Valmont eller Don Juan rollen som forløbere for den franske revolution eller for kvindernes frigørelse. Baudelaire bemærkede i sine noter til Farlige Forbindelser, at libertinerne ikke forberedte den franske revolution, men at de ved deres blotte eksistens gav en forklaring på, hvorfor den måtte komme. ${ }^{7}$ De var et eksempel på den sociale koldbrand, der havde bredt sig i samfundets herskende klasser. Libertinage var blevet en erstatning for tidligere tiders heroisme. Adelsmændene var ikke længere tvunget til at kæmpe for Frankrig, og de måtte i stedet kæmpe mod den smertefulde bevidsthed om deres egen eksistens' tomhed. Kvinder havde så erstattet fjendehæren, den som man skulle belejre, besejre og udøve sin magt over. Kraftpræstationerne i alkoverne erstattede heltegerningerne på slagmarken. 
Det vigtige her er, at libertineren aldrig i modsætning til soldaten kan være oprigtig. Han er nødt til at foregive noget for at sejre. Og det, han gør, er at forklæde sig som det godes sendebud: Han er ikke en simpel forfører, nej, han er et redskab i Guds (eller naturens) oprindelige plan. Han ønsker at frigøre kvinderne fra dumme fordomme og sociale konventioner. Han vil give dem tilbage til det, de virkelig er.

Men i virkelighedens verden spreder libertineren ødelæggelse og fortvivlelse omkring sig, og når masken falder, viser det sig, at ingen går mere op i konventioner og social prestige end ham. Det bliver gang på gang klart, at der er klare grænser for, hvad man kan tillade sig som libertiner. Valmont er nødt til at forlade Madame de Tourvel (som han elsker til døden!), fordi libertinerkonventionerne kræver det. Han ville fremstå som latterlig, hvis det kom frem, at han virkelig elskede en kvinde. Den kontrol, som libertinerne udøver over deres egne følelser, er kun mulig, fordi de er fuldkommen følelsesforladte. De er tomme indvendig og kan derfor uden problemer spille den rolle, som den offentlige mening beder dem om at spille.

Med en omformulering af mit oprindelige spørgsmål kan vi nu spørge, om Sade tilhører den ene eller den anden retning. Er det en erotisk utopi, eller er det problematiseringen af en erotisk utopi, vi har med at gøre?

\section{Sade og libertineridealet}

Takket være surrealisterne er Sade blevet et ikon i litteraturhistorien. Derfor har man også en naturlig tendens til at undskylde de handlinger, der sendte ham i fængsel. Han sad i fængsel i over 27 år, og det ødelagde hans liv fuldstændig.

På hans generalieblad står i det store og hele tre sager. I 1763, da Sade er 23 år gammel (og nygift i øvrigt med den højadelige og hovedrige Rose Pélagie de Montreuil), lukker han en fattig og gravid arbejderpige, Jeanne Testard, inde, tvinger hende til at profanere krucifikset og udsætter hende for diverse ydmygelser, bl.a. giver han hende lavementer. Hun undslipper og går direkte til politiet, og Sade må tilbringe et par dage i fængsel. Det får ham dog ikke til at opgive libertinagen, der fylder det meste af hans vågne tid. Påskesøndag 5 år efter, i 1768, lokker han en ung tiggerpige, Rose Keller, ud til et lille slot, som han ejer. Han sætter hende en pistol for panden, tvinger hende til at tage tøjet af, pisker hende voldsomt og skærer hende i ryggen med en kniv. Hun undslipper også, og denne gang må Sade sidde i fængsel helt til november samme år. Endelig 4 år efter i 1772 bliver Sade dømt til døden af parlamentet i Aix-en-Provence for sodomi og forsøg på forgiftning. Han er blevet anmeldt af 4 prostituerede, som han har givet bolsjer med spansk flue, et kendt og desværre både uvirksomt og giftigt afrodisiakum. De bliver forfærdelig syge og anmelder Sade, fordi de frygter, at han har forgivet dem.

Sade flygter og bliver senere benådet, men i 1777 har hans familie og svigerfamilie fået nok. De holder op med at beskytte ham, og hans svigermor, der har fået omstødt dødsdommen, får ham sat i fængsel, hvor han tilbringer de næste 12 år. Han bliver løsladt i 1790, men også i årene efter bliver han fængslet flere gange under forskellige påskud. Han begår ikke nye forbrydelser, men det er tydeligt, at man frygter ham og gerne ser ham buret inde. Som sagt kommer han til at tilbringe i alt 27 år af sit liv i 11 forskellige fængsler. 
Det er ganske bemærkelsesværdigt, at den franske enevælde fængsler et medlem af den ældste, fornemste og mest magtfulde adelsslægt i Frankrig for overgreb på kvinder fra almuen. ${ }^{8}$ Men der er ingen tvivl om, at Sade, da han sættes i fængslet i Vincennes i 1777, både er en overbevist libertiner og et generelt depraveret og frastødende individ. Spørgsmålet er (for at give det en tredje formulering), om de bøger, som Sade begynder at skrive efter fem års indespærring, er en forsvarstale for det libertinerliv, som han havde praktiseret de 15 foregående år, og som havde sendt ham i fængsel, eller om det er en kritik af det.

\section{Fæstningen i Silling}

Det er fængslet, der gør Sade til forfatter. I 1782 begynder han at skrive De 120 dage i Sodoma. I tre år skriver han med mikroskopisk håndskrift på små $12 \mathrm{~cm}$ brede papirlapper, som han limer sammen til et 12 meter langt bånd, der kan rulles sammen og gemmes. Da Sade pludselig bliver overført fra Bastillen til Charenton-fængslet natten til den 4. juli 1789, græder han "tårer af blod" over, at han må efterlade den dyrebare rulle i sin celle. Da Bastillen falder et par dage efter, får en anden adelsmand fat i manuskriptet. Det er i privateje (og Sade selv ser det aldrig mere), indtil det bliver købt af den tyske psykiater Iwan Bloch, der udgiver en meget fejlbehæftet oversættelse i 1904. Det er først i 1930'erne, at manuskriptet erhverves af Maurice Heine, der omsider sørger for en ordentlig udgave på fransk af et værk, der kun kan betegnes som et af verdenslitteraturens mest radikale skrifter.

Hvad handler De 120 dage i Sodoma om?

Henimod slutningen af Ludvig den Fjortendes regeringstid lukker fire libertinere sig inde på slottet Silling dybt inde i Schwarzwald. Med sig har de deres hustruer, fire ruffersker, der bliver kaldt historiefortællerne, otte unge mænd, otte unge piger og otte "kneppere" ("fouteurs"), plus lidt personale til at lave mad og betjene herskabet. Alle slottets beboere har kun til formål at tjene til de fire libertineres tilfredsstillelse, og udskejelserne går ind i et fire måneder langt og nådesløst crescendo. Det nøje udvalgte menneskelige materiale, der er blevet ført til Silling, kan ikke vente hjælp udefra; det er på forhånd dømt til at gå til spilde i en metodisk eksperimenteren med alle seksuelle perversioner. Hver dag har sin nye perversion i en ubønhørlig overbudspolitik mod det mere og mere grusomme og blodige. Begærets dynamik næres nemlig kun af en ting: overskridelsen. Når noget er prøvet, er det uinteressant: been there, done that. Andre overskridelser er nødvendige. Og andre igen og igen. Da teksten nærmer sig sin slutning, er der kun 16 overlevende af de 46 oprindelige deltagere i orgiet. Sade opgav i øvrigt at gøre teksten færdig, og det er ikke så underligt, at han gik i stå: Han var nået ind i rædslens hjerte, længe før de 120 dage var gået.

Trods det radikalt anderledes ved Sade er der flere traditionelle narrative elementer. Man genkender strukturen med historiefortællernes indlejrede beretninger fra Tusind og en nats eventyr, Boccacios Dekameron og Marguerite de Navarres Heptaméron. Selve iscenesættelsen ligner også de to renæssancetekster: Et udsøgt selskab er strandet på et slot, hvor de fordriver tiden med at fortælle historier og anekdoter. 
Overordnet er teksten organiseret efter et 4-tals princip. De fire måneder (fra november til februar), som handlingen strækker sig over, svarer til fire stadier (passions simples, passions doubles, passions violentes, passions meurtrières) i forbrydelserne og deres tilsvarende straffe. De fire libertinere repræsenterer ikke blot den antikke lægekunsts fire temperamenter, men også enevældens fire eliter: militæret, kirken, politikken og finansverdenen. Det er med andre ord et repræsentativt udvalg af samfundets top, som Sade har samlet. De viser sig dog, at de fire typer i løbet af handlingen sætter sig ud over og neutraliserer den fysiologiske, psykologiske og sociale determinisme, for de forenes og bliver ét i den rene ondskab.

Der findes altså en række narrative og konceptuelle forbilleder for Sades tekst. Det er dog mest forskellene, der springer i øjnene. Afsondringen hos Sade skyldes således ikke en pestepidemi som i Dekameron eller et uvejr som i Heptameron. Den er planlagt og villet og svarer til et rationelt projekt: forsøget på at komme til bunds i de menneskelige lidenskaber.

Stedet er heller ikke traditionens locus amoenus, men et fuldstændig afsondret, rædselsvækkende, labyrintisk middelalderslot, hvis uhyggelige ydre passer til den uvejsomme og utilgængelige natur omkring det. Det er et hermetisk lukket og klaustrofobisk sted. Dørene er muret til: De er ikke blot uigennemtrængelige, de er usynlige.

Silling fremstår også som den absolutte modsætning til libertinerromanens typiske locus amoenus: det lille lystslot for enden af parken, springvandets pludren, alkoven med Amor-statuen og så videre. Ikke blot erstatter og sletter slottet i Silling libertinerromanens utopiske sted. De to steder svarer til to helt forskellige opfattelser af den menneskelige natur. På den ene side den gode menneskelige natur, hvis begær er legitimt, hvis lyst vil føre hele samfundet til en generaliseret lyksalighed. Libertinerutopiens locus amoenus er et billede på det gennemsigtige jeg, der søger sin egen og andres lykke. Et jeg, som man kan stole på, fordi det som sit højeste mål har det universelt Gode.

Det billede af den menneskelige natur, som Sades utilgængelige middelalderslot udtrykker, er ganske anderledes. Det er et uigennemtrængeligt jeg, der farer vild i endeløse, labyrintiske og mørke korridorer. Den rædsel, der griber personerne, er rædslen over for menneskenaturen, hvor mørke, ukendte og onde kræfter arbejder dybt nede i bevidsthedens lag. Slottet i Silling er en implicit, men voldsom kritik af libertinerutopiens illusioner om menneskehedens natur.

Sade er i øvrigt ganske eksplicit omkring det. I et lille essay "Idée sur les romans"9 skriver han, at romanens mål er at vise mennesket, som det er, at studere menneskehjertets løngange og beskrive den ulykke, som onde mennesker kan forårsage.

4f [Romanerne] tjener til at male jer, som I er. Hovmodige individer, der vil undgå penslen, fordi I er bange for resultatet. [...] Historiens mejsel viser kun mennesket, når det viser sig frem, og så er det ikke længere sig selv; ambitionen, hovmodet dækker dets pande til med en maske, der kun viser disse to lidenskaber og ikke mennesket selv. Romanens pensel derimod viser det indefra... viser det, når det lader masken falde, og tegner det på en måde, der både er meget mere interessant og sandere: Det er nytten ved romaner. ${ }^{10}$ 
Romanen skal være et bolværk mod den skadelige påvirkning fra libertinerromanens lovsange om den menneskelige natur. Menneskenaturen er - skriver Sade - en vulkan: "Menneskehjertet er i evig uro og ligner det indre af en vulkan, der skiftevis udspyr enten dyrebare stene, som menneskene kan smykke sig med, eller ildkugler, der tilintetgør dem". ${ }^{\text {II }}$ Mennesket er fuldstændig uforudsigeligt, i stand til alt, godt som ondt. Det er en alvorlig fejltagelse at tro, at mennesket spontant $ø$ nsker det gode.

\section{Sodomas helvede}

Der er - også i den kritiske tradition - en vis enighed om Sades forsøg på at problematisere den menneskelige natur. Men er løsningen at give sig naturen i vold? At leve sine lyster ud?

Det er temmelig gådefuldt, hvordan nogen har kunnet se De 120 dage i Sodoma som et værk, der fejrede eller advokerede for begærets fuldstændige og lykkelige frigørelse. Romanens fire hovedpersoner kender ingen grænser, men de er også selv fanget i en blindgyde og en dødsspiral. De betragter sig selv som overmennesker, men de kan kun hævde denne rang ved at nedværdige sig selv og andre. Da de starter deres udforskning, har de allerede længe været fuldstændig kolde over for normal sex. De har seriøse potensproblemer, og intet kan ophidse dem mere. Hele iscenesættelsen - fire måneders uafbrudt orgie med 42 kroppe stillet til deres rådighed - har som eneste mål at få dem til at føle bare lidt begær igen.

På slottet hersker der en jerndisciplin. Fangerne er blevet berøvet enhver form for personlighed og kropslig autonomi. De er en samling menneskelige reservedele, der indgår i vanvittige og næsten abstrakte geometriske balletter af forvredne kroppe. De fire kvinder, der er indforskrevet som historiefortællere, skal give inspiration til udfoldelserne. Det er på den måde, vi hører om libertinere, der kun kan få den op at stå, når de har spist lort fra en smuk kvinde, eller som kun kan komme, når en kvinde kaster op i munden på dem, eller som kun kan føle lyst, når de hiver øjne ud, skærer gravide maver op, mæsker sig i indvolde og så videre og så videre ad nauseam. (Det er de færreste læsere, der holder ud så længe. Man er syg, når man har læst værket til ende, bemærkede Georges Bataille).

Mange - selv overbeviste Sade-tilhængere - har været uforstående over for Sades tilsyneladende meningsløse insisteren på det ulækre. Hvad er eksempelvis pointen med at spise lort hele tiden? ${ }^{12}$

Pointen er lige præcis, at Sades intention er at fremkalde lede og ikke lyst. Han vil ikke male et fortryllende billede af, hvor dejligt alting bliver, når vi giver os vore sanser og begær i vold. Pointen er at vise, at libertinagen er en mekanik, der fører frem mod det uudholdelige. Slotsherrerne på Silling er (ligesom deres ofre) fanger af den logik.

4 Der findes et ordsprog (og ordsprog er en rigtig god ting), der findes altså et ordsprog, siger jeg, der hævder, at appetitten kommer, mens man spiser. Dette ordsprog, hvor groft det end er, har en meget vid betydning: det siger, at man ved at gøre rædselsgerninger får lyst til at gøre nye rædselsgerninger, og at jo flere man begår, jo flere får man lyst til at begå. Det var historien om vores umættelige libertinere. ${ }^{\mathrm{I} 3}$ 
Sex er overskridelse. Og - hvis man følger Sade - sex appellerer til os ikke på grund af den fysiske lyst, som vi føler, men på grund af de overskridelser, som sex indebærer og muliggør. Der er desværre det problem med overskridelser, at de hurtigt mister deres skarpe smag, når de bliver gentaget. Nye overskridelser er påkrævet. Tabuet er den trylledrik, der kan genoplive begæret, men tabuerne står også for fald. Når alle tabuer er krænkede (dyresex, pædofili, nekrofili, incest), ender man før eller siden foran det sidste tabu: Du må ikke slå ihjel!

Libertinagen hos Sade bærer en destruktiv logik, der forvandler de muntre tilhængere af seksuel frigørelse til det Ondes apostle. Det originale og det ovenud vellykkede ved De 120 dage i Sodoma er at give læseren en næsten fysisk oplevelse af denne ubønhørlige dødedans, denne lange nedstigning, der starter i en lystfuld, liderlig atmosfære, men som ender i helvedes inderste cirkel.

\section{Sade, som han er}

Sade er ikke dumpet ned som en meteor i den franske litteratur. På mange punkter skriver han sig ind i romantraditionen fra Crébillon fils, Duclos og Laclos, der iscenesætter libertinerpersoner som onde og skadelige. Denne simple konstatering går underligt nok direkte imod, hvad den herskende kritiske tradition siger om Sade, nemlig at han er fortaler for den absolutte libertinage. Når alt kommer til alt, var Sade så ikke selv libertiner? Skulle han skrive mod sig selv?

Ifølge surrealisterne (men også helt moderne fortolkere som Pierre Naville og Annie Le Brun) forsvarede Sade til den bitre ende det liv, som han levede i sine unge år. Tesen er kort sagt: 1) at det var en libertiner, der blev sat i fængslet i Vincennes i 1777; 2) at fængslet kun bestyrkede ham i hans libertineroverbevisninger; 3) at hans værk er et langt forsøg på at udfordre samtidens konventioner og hævde retten som libertiner.

Denne meget udbredte tese har to problemer. For det første er det ubegribelig svært at betragte romanerne som lovprisninger af den seksuelle frigørelse, når de nu rent faktisk viser de forfærdelige konsekvenser af den. For det andet: Den person, der bliver fremstillet som fuldstændig urokkelig i sine overbevisninger efter 27 års fængsel, virker ikke som en genial forfatter. Han virker tværtimod som en ualmindelig indskrænket person, en monoman galning. Casanova ændrede sig ikke i sin alderdom; han sad ensom og syg og længtes tilbage og prøvede at varme sig ved minderne. Men Sade mistede alt. I fængslet var han plaget af sygdom. Den seksuelle frustration var uudholdelig. Han faldt fra samfundets absolutte top til dets absolutte bund. Han blev ruineret. Hans familie gik i opløsning. Han rasede mod sin svigermor (en kvinde, en simpel genstand, mens han, Marquis de Sade var en libertiner, en gud), der havde forårsaget hans fald og hans totale sociale fallit. Men han var også klar over, at der var én og kun én ansvarlig for hans fald, og det var ham selv.

I 15 år levede han som libertiner, og han havde selv oplevet at blive fanget i overskridelsesparadokset. Mange har således bemærket, at Sade formentlig var sluppet uden straf for anklagen fra Rose Keller, hvis ikke han havde bortført hende lige præcis en påskesøndag. Det var dagen, mere end ydmygelserne, der gav anledning til 
skandalen, og Sade havde selvfølgelig valgt den, fordi han så ved samme lejlighed kunne overskride både de sociale og religiøse love. Men helt ærligt: er den fysiske vellyst større en påskesøndag end alle andre dage i året?

Der er en dødsdrift i libertinerens evige overbudspolitik, og den vil før eller siden få ham til at gå for langt. Sade blev smidt i fængsel og måtte modstræbende give afkald på forestillingen om at være et overmenneske og i stedet spørge sig selv, hvorfor hans tilværelse havde udviklet sig til en katastrofe. Han giver selv svaret $\mathrm{i}$ et brev til sin kone: Hans fald skyldtes, at han fra barnsben var blevet opdraget til at tro, at han tilhørte en kaste, der bestemte alt i denne verden, og som ikke behøvede at bekymre sig om andre. ${ }^{14}$ Han var som andre unge adelsmænd på den tid et egoistisk monster, der i libertinagen fandt en passende udtryksform, en måde hvorpå han kunne demonstrere sin magt over verden, en måde der oven i købet var legitimeret af tidens filosofi, for hævder Helvetius, La Mettrie, og D'Holbach ikke lige præcis, at alle lidenskaber er legitime?

Sades skrifter er ikke et forsøg på at forsvare hans ulykke, men et forsøg på at forstå grundene til den. Sade tænker ikke - eller rettere: Sade tænker ikke længere som sine personer.

I revolutionsårene var Sade på fri fod, og han spillede en vis rolle som revolutionær sektionsleder i Paris. En ganske paradoksal rolle! Hvis man skal dømme efter hans opførsel som revolutionær, står det klart, at libertinerne i hans romaner ikke er forbilleder, men skræmmebilleder. Han var således imod dødsstraf, han stemte mod dødsstraf til kongen, han stemte endda mod dødsstraf til sin tidligere svigerfamilie på trods af, at han hadede dem som pesten. Dagen før Robespierres fald (et magtskifte, der reddede Sades liv) blev han endda selv dømt til døden for "moderantisme". Det må vist være topmålet for en sadist.

\section{Noter}

I Hans Bjerregaard: "Sadisme og kedsomhed", Ekstra Bladet, 6.1.2008, p. 34.

2 Tilgængelig i engelsk oversættelse på http://www.archive.org/details/psychopathiasexu00kraf (senest besøgt 4.9.2008).

3 Apollinaire, Guillaume: L'oeuvre du Marquis de Sade, Paris: Bibliothèque des Curieux, 1909.

4 Alain Robbe-Grillet: "Sade et le joli", i Obliques, 12-13, 1977, p. 59.

5 Dette citat er bedst på fransk: "Pour Sade, il n'y a d'érotique que si l'on « raisonne le crime »; raisonner, cela veut dire philosopher, disserter, haranguer, bref soumettre le crime (terme générique qui désigne toutes les passions sadiennes) au système du langage articulé ; mais cela veut dire aussi combiner selon des règles précises les actions spécifiques de la luxure, de façon à faire de ces suites et groupements d'actions une nouvelle « langue », non plus parlée mais agie : la « langue » du crime, pour nouveau code d'amour, tout aussi élaboré que le code courtois," Roland Barthes: "L'arbre du crime", i Tel Quel, 28, 1967, p. 30.

6 Denis Hollier: “Surrealist Precipitates: Shadows Don’t Cast Shadows”, i October, vol. 69, summer, 1994, p. 113.

7 Charles Baudelaire: CEuvres complètes, Paris: Gallimard, Bibliothèque de la Pléiade, vol. II, 1976, p. 68. 
8 Sades forfader, Hugues de Sade, var fx gift med den Laura, Laure de Noves, der blev tilbedt og besunget af Petrarca i det 14. århundrede.

9 Sade: Oeuvres complètes du marquis de Sade, Paris: Cercle du Livre précieux, vol. X, 1966, p. 19.

Io "Ils [les romans] servent à vous peindre tels que vous êtes. Orgueilleux individus qui voulez vous soustraire au pinceau, parce que vous redoutez les effets, [...] Le burin [de l'histoire] ne peint l'homme que lorsqu'il se fait voir, et alors ce n'est plus lui ; l'ambition, l'orgueil couvrent son front d'un masque qui ne nous représente que ces deux passions, et non l'homme. Le pinceau du roman, au contraire, le saisit dans son intérieur.... le prend quand il quitte ce masque, et l'esquisse, bien plus intéressante, et en même temps plus vraie : voilà l'utilité des romans." Sade: Op. cit., vol. X, 1966, pp. 15-6.

II “... son sein, toujours agité, ressemble au foyer d'un volcan, d'où s'élancent tour à tour, ou des pierres précieuses servant au luxe des hommes, ou des globes de feu qui les anéantissent." (Sade: Op. cit., vol. X, p. 19)

I2 Gilbert Lély, der ellers skriver sig ind i den hagiografiske Sade-tradition, mener fx at det går ud over sandsynligheden, at Sade insister på lortefortæringen, der med fordel kunne være erstattet af mere egentlig erotiske aktiviteter. Gilbert Lély: Sade. Étude sur sa vie et sur son œuvre, Paris: Gallimard, 1967, p. 219.

I3 "Il y a un proverbe (et c'est une fort bonne chose que les proverbes), il y en a un, dis-je, qui prétend que l'appétit vient en mangeant. Ce proverbe, tout grossier qu'il est, a pourtant un sens très étendu: il veut dire qu'à force de faire des horreurs, on en désire de nouvelles, et que plus on en fait, plus on en désire. C'était l'histoire de nos insatiables libertins." Sade, Op. cit., vol. I, p. 291. I4 Sade: Op. cit., vol. I, p. 21.

\section{Litteratur}

Apollinaire, Guillaume: L'OEuvre du marquis de Sade, pages choisies, introduction, essai bibliographique et notes par Guillaume Apollinaire, Paris: Bibliothèque des Curieux, 1909.

Barthes, Roland: "L'arbre du crime”, i Tel Quel, 28, 1967.

Barthes, Roland: Sade, Fourier, Loyola, Paris: Seuil, 1971.

Bataille, Georges: "Sade et l'homme normal" \& "L'homme souverain de Sade" i L'érotisme, Paris: Editions de Minuit, 1957.

Baudelaire, Charles: CEuvres complètes, Paris, Gallimard, Bibliothèque de la Pléiade, vol. II, 1976.

Blanchot, Maurice: Lautréamont et Sade, Paris: Éditions de Minuit, 1963.

Blanchot, Maurice: Sade et Restif de La Bretonne, Paris: Complexe, 1986.

Breton, André: “D.A.F. de Sade”, i Anthologie de l’humour, Paris: Éd. du Sagittaire, 1939.

Brix, Michel: Sade et les félons, Jaignes: La Chasse au Snark, 2003.

Hénaff, Marcel: Sade, l'invention du corps libertin, Paris: PUF, 1978.

Hollier, Denis: “Surrealist Precipitates: Shadows Don't Cast Shadows", i October, vol. 69, summer, 1994, pp. 110-132.

Klossowski, Pierre: Sade mon prochain, Paris: Seuil, 1947.

Lély, Gilbert: Sade. Étude sur sa vie et sur son œuvre, Paris: Gallimard, 1967.

Le Brun, Annie: Les Châteaux de la subversion, Paris: J-J Pauvert, 1982.

Le Brun, Annie: Soudain un bloc d'abîme, Sade, Paris: J-J Pauvert, 1986.

Le Brun, Annie: Sade, aller et détours, Paris: Plon, 1989. 
Robbe-Grillet, Alain: "Sade et le joli", i Obliques, 12-13, 1977.

Sade, Donatien Alphonse François: OEuvres complètes du marquis de Sade, Paris: Cercle du Livre précieux, vol. I-XVI, 1961-7.

Sade, Donatien Alphonse François: Lyst og forbrydelse. Udvalg, oversættelse og efterskrift ved Kim Witthoff. København: Tiderne Skifter, 2007. 